\title{
US immigration moves raise fears over ease of entry for scientists
}

Washington. University organizations and immigration lawyers are warning that legislation now moving through the US Congress could make it more difficult for foreign scientists and engineers to enter the country. But they disagree about just how difficult.

Their concern has been triggered by a bill introduced into the House of Representatives in June by Lamar Smith (Republican, Texas) that would require some US companies and universities wishing to employ foreign researchers to demonstrate that no American workers are qualified for the job.

Congress is keen to reform the immigration laws during this legislative term, partly in response to public anxiety about illegal immigrants, who compete with American workers and use social services supported by US taxpayers. In addressing such issues, Congress is likely to place new restrictions on legal immigration as well.

Smith's bill, designated H.R.1915, would reduce legal employment-based immigration from its current level of 140,000 a year to 135,000 a year. That alone is not a significant reduction, particularly as fewer than
100,000 such visas are currently granted.

But the bill also changes the categories under which foreigners seeking jobs in the United States can be admitted. In particular, it eliminates the "outstanding researchers" designation whereby highgrade scientists and engineers are exempted from the certification process designed to prove that no US workers are available. Some 1,800 visas were granted under this provision last year.

Legal aliens could escape certification if they have "extraordinary ability in the sciences, arts, education, business, or athletics which has been demonstrated by sustained national or international acclaim". But foreigners with advanced degrees but only "exceptional ability" - and a third tier of "skilled workers and professionals" would have to follow conventional channels.

Elissa McGovern, a policy analyst with the American Immigration Lawyers Association (AILA), describes the latter as an "elaborate and very long process" that may discourage universities and private companies from hiring foreign researchers. She

\section{Soliton wave receives crowd of admirers}

\begin{abstract}
London. Scientists at HeriotWatt University in Edinburgh, Scotland's capital city, last month took to the water (right) to honour a Victorian civil engineer for a discovery he made 161 years ago.

John Scott Russell, better known for his successes in ship hull design and the first experimental demonstration of the Doppler effect, is also the first person to have correctly identified a soliton wave, while watching a boat on Edinburgh's Union Canal.
\end{abstract}

Last month, scientists attending a conference at Heriot-Watt University on nonlinear waves in physics and biology witnessed a reconstruction of that first sighting. The occasion was part of a ceremony to name a new aqueduct after Russell.

A soliton is a nonlinear wave that is able to propagate without spreading out, breaking up or losing strength over distance. It is now the basis of an established method for transporting data through fibre optic cables.

Russell witnessed such a wave while watching a boat being drawn along the also says fewer visas will be available for scientists and engineers, as there will now be in competition in the same category with executives from multinational corporations coming to work in the United States.

But others are less alarmist than AILA, claiming that H.R.1915's category-shifting, while adding some hassle and expense, is unlikely to discourage scientists and engineers coming into the United States.

George Fishman, for example, a staff member on the House immigration subcommittee chaired by Smith, says there is a very high approval rate - more than 90 per cent - for labour certifications. While acknowledging that companies or universities who want to hire non-US researchers may "have more work ahead of them," he believes that in most cases the visas should go through.

John Vaughn of the Association of American Universities (AAU) says that eliminating the 'outstanding researcher' category may pose a problem for universities if the labour certification process becomes so congested that highly-prized faculty members cannot be promised quick entry into the United States. Vaughn says Smith's staff has made it clear he would consider amending the bill to help eliminate this problem.

Smith showed his willingness to bow to university interests last month, when he added an amendment to H.R.1915 that would solve what many believe is a much more serious problem for universities. This was a policy followed by the US Department of Labor (DOL) requiring that foreign researchers, even at postdoctoral level, be paid at industry rates rather than the lower rates normally paid to academic workers.

Acting on a little-publicized ruling by an administrative court earlier this year, the DOL has been cracking down on universities in recent months, insisting that they raise their rates of pay for foreign workers.

But the AAU and other university organizations have asked the DOL to place a moratorium on this practice, arguing that industry and universities represent different kinds of labour market. Smith's amendment to H.R.1915 specifically says that universities would have only to pay rates comparable to those at other universities.

Meanwhile, the Senate is taking its own look at immigration reform. Alan Simpson (Republican, Wyoming), a conservative legislator who has long been an advocate of restricting immigration, now chairs the Senate panel responsible for rewriting the law.

Simpson plans to introduce a bill on legal immigration within the next two weeks that some believe will be more restrictive than the House version. His bill may even set 